\title{
Modifications to a One-Dimensional Model of Unsteady Flow in the Colorado River Through the Grand Canyon, Arizona
}

By STEPHEN MARK WIELE and ELEANOR R. GRIFFIN

Water-Resources Investigations Report 97-4046

Prepared in cooperation with the Bureau of Reclamation 


\section{U.S. DEPARTMENT OF THE INTERIOR \\ BRUCE BABBITT, Secretary}

\section{U.S. GEOLOGICAL SURVEY}

Thomas J. Casadevall, Acting Director

This report supercedes U.S. Geological Survey Water-Resources Investigations Report 97-4046 that was printed in 1997.

The use of firm, trade, and brand names in this report is for identification purposes only and does not constitute endorsement by the U.S. Geological Survey.

For additional information write to:

Regional Research Hydrologist, CR

U.S. Geological Survey

Water Resources Division

Box 25046, MS418

Denver, CO 80225
Copies of this report can be purchased from:

U.S. Geological Survey Information Services Box 25286

Denver Federal Center Denver, CO 80225 


\section{CONTENTS}

Abstract

Introduction

Model overview

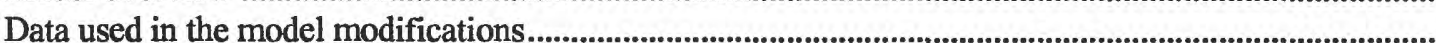

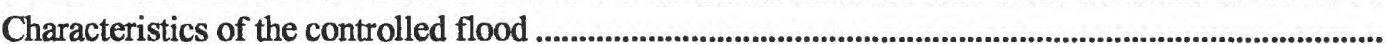

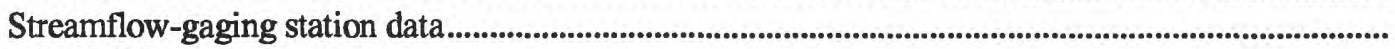

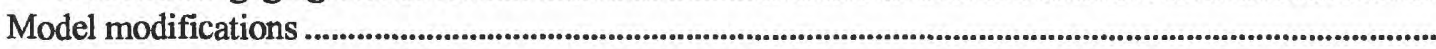

Govening equations

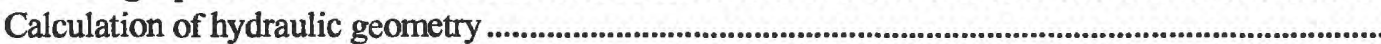

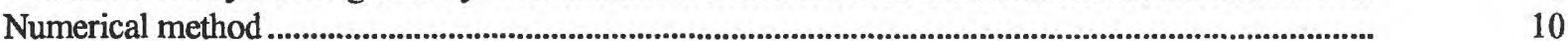

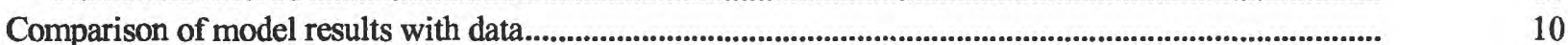

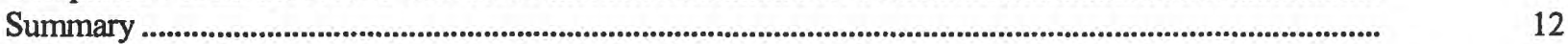

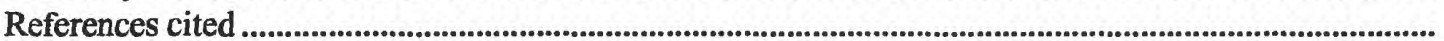

\section{FIGURES}

1. Map showing the modeled reach of the Colorado River from Glen Canyon Dam to Diamond Creek

2. Hydrograph for the controlled flood realeased from Glen Canyon Dam, March-April 1996

3-7. Graphs showing:

3. Wave speed calculated from the hydrographs from the streamflow-gaging stations, Colorado River at Lees Ferry and Colorado River above Diamond Creek near Peach Springs, calculated with equation 7, and calculated by differentiating the steady-flow discharge as a function of area calculated from the hydraulic geometry used in the original model.

4. Relation between friction coefficient, $\beta$, and hydraulic radius

5. Wave speeds calcuated with equation 7 and by differentiating discharge $(Q)$ with respect to cross-sectional area (A) in equation 9.

6. Relation between the hydraulic radius and the friction coefficient, $\beta$, calculated by using equation $\left(\beta=Q_{k}\left(A u_{*}\right)\right)$ in which cross-sectional area $(A)$ is taken from equation 8 and using equation 10 .

7. The derivative of the friction coefficient, $\beta$, with respect to the hydraulic radius plotted against the hydraulic radius.

8. Hydrographs determined from stage records and stage-discharge relations at streamflow-gaging stations, Colorado River above the Little Colorado River near Desert View and Colorado River near Grand Canyon, for the receding limb of the controlled flood

9. Graph showing wave speeds calculated from the hydrographs shown in figure 8

10-13. Hydrographs calculated with the original and modified models and hydrographs determined from the stage records and the stage-discharge relations for:
10. Research flow B
11. Research flow D
12. Rising and falling limbs of the controlled flood at the streamflow-gaging station,
Colorado River above the Little Colorado River near Desert View
13. Rising and falling lims of the controlled flood at the streamflow-gaging station,
Colorado River near Grand Canyon 
14. Hydrographs calculated with the original and modified models and hydrographs determined from the stage records and stage-discharge relations or rising and falling limbs of the controlled flood at the streamflow-gaging station, Colorado River above Diamond Creek near Peach Springs ..

\section{TABLES}

1. Model error on rising limb of the controlled flood at three streamflow-gaging stations for the original and modified models.

2. Model error on falling limb of the controlled flood at three streamflow-gaging stations for the original and modified models.

\section{CONVERSION FACTORS}

\begin{tabular}{rrrl}
\hline & & By & To obtaln \\
\hline & meter $(\mathrm{m})$ & 3.281 & foot \\
& kilometer $(\mathrm{km})$ & 0.6214 & mile \\
& square meter $\left(\mathrm{m}^{2}\right)$ & 0.0002471 & acre \\
cubic meter per second $\left(\mathrm{m}^{3} / \mathrm{s}\right)$ & 70.07 & acre-foot per day \\
\hline
\end{tabular}




\title{
Modifications to a One-Dimensional Model of Unsteady Flow in the Colorado River Through the Grand Canyon, Arizona
}

\author{
By Stephen Mark Wiele and Eleanor R. Griffin
}

\begin{abstract}
Calculations of the downstream progression and evolution of discharge waves released from Glen Canyon Dam on the Colorado River through Grand Canyon have been based on hydraulic geometry derived from measurements made at a maximum discharge of 792 cubic meters per second. Predictions of downstream hydrographs for larger discharges, such as the controlled flood in March-April 1996, which reached a maximum release of 1,270 cubic meters per second, have been based on extrapolations of that hydraulic geometry. Data from the controlled flood have been used to extend the model to higher discharges using a method that differs from that used to determine hydraulic geometry in the original model. Scaling of the momentum equation shows that the wave is well represented by the kinematic-wave equation on the receding limb of the controlled-flood hydrograph. The wave speed as a function of discharge can be determined from data obtained at streamflow-gaging stations. The wave speed, which is equal to $d Q_{k} / d A$, where $Q_{k}$ is the steady-flow discharge and $A$ is the cross-sectional area, then can be integrated to determine the relation between discharge and cross-sectional area of the channel. A known value of the area corresponding to a given discharge supplies the integration constant. This procedure has yielded a modified hydraulic geometry for the model of flow in the Colorado River between Glen Canyon Dam and Lake Mead that has been extended to 1,270 cubic meters per second. A numerical method modified for higher rates of change in discharge and the new hydraulic geometry have improved the accuracy of the model for discharges greater than about 800 cubic meters per second.
\end{abstract}

\section{INTRODUCTION}

The one-dimensional model of unsteady flow in the Colorado River in the Grand Canyon (fig. 1) presented by Wiele and Smith (1996) has been used to predict hydrographs along the river corridor in support of research conducted in the canyon (Griffin and Wiele, 1995). The model has been used by the U.S. Geological Survey (USGS) to estimate discharge at streamflow-gaging stations where data are missing. Before the controlled flood ${ }^{1}$ in late March and early April 1996, predictions of the hydrographs at the streamflow-gaging stations were published to help in the preparation and execution of field experiments (Wiele, 1996). The accuracy of these predictions, however, was limited by the absence of

\footnotetext{
'The Grand Canyon Monitoring and Research Center refers to this event as a "beach/habitat-building flow" (L.D. Garrett, Chief, Grand Canyon Monitoring and Research Center, written commun., 1997).
} 


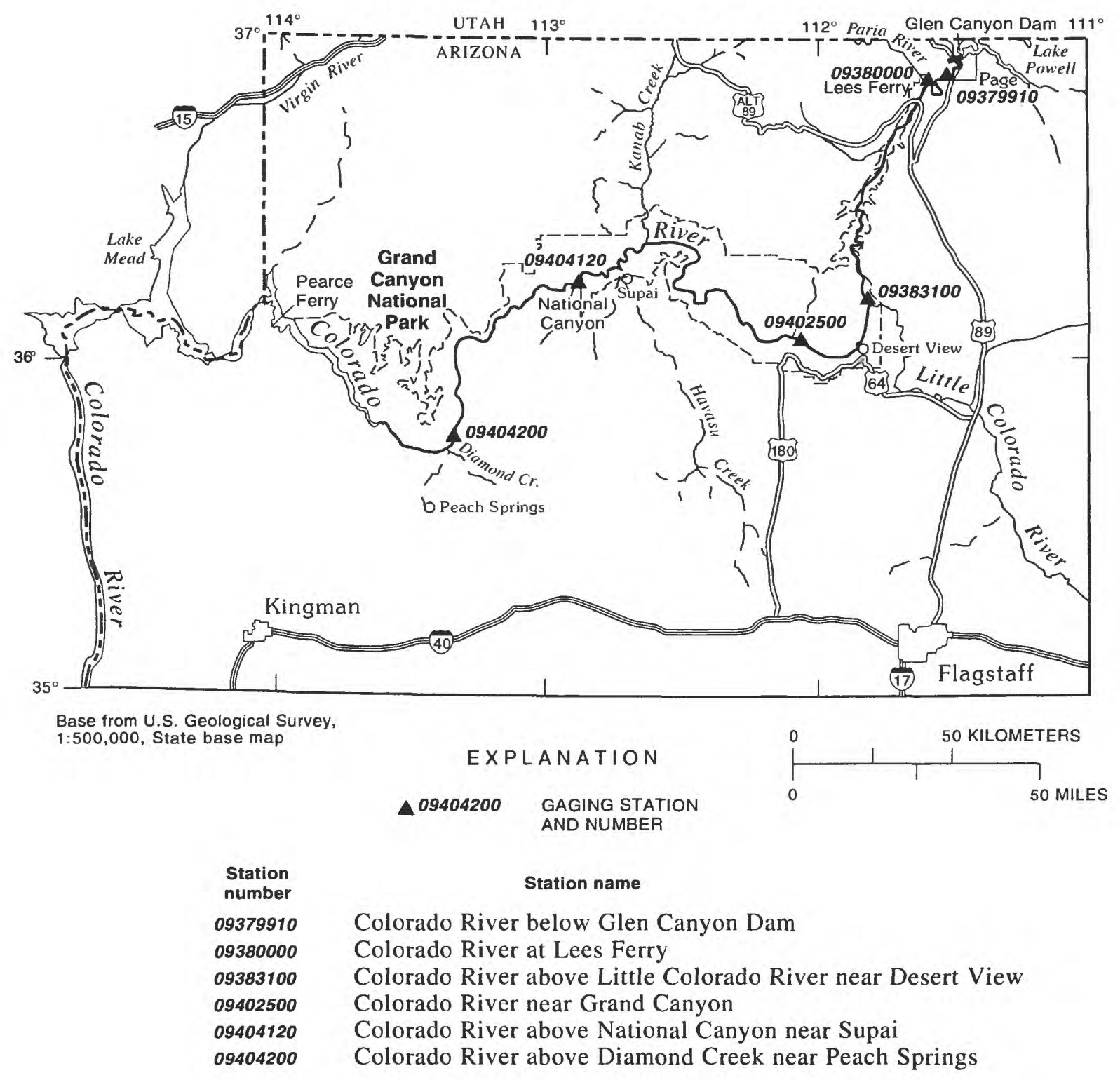

Figure 1. Modeled reach of the Colorado River from Glen Canyon Dam to Diamond Creek.

data for discharges above the maximum discharge (about $934 \mathrm{~m}^{3} / \mathrm{s}$ ) that can be accommodated by the turbines at the powerplant at Glen Canyon Dam, which required extrapolation of the hydraulic geometry to the controlled-flood maximum of $1,270 \mathrm{~m}^{3} / \mathrm{s}$.

The hydraulic geometry used in the model has been extended to $1,270 \mathrm{~m}^{3} / \mathrm{s}$ by applying kinematic-wave theory to the receding limb of the controlled-flood hydrograph to infer a new hydraulic geometry. In addition, the model has been modified using a numerical method that calculates more accurately the rapid changes in discharge associated with the controlled flood. This report documents these modifications to the model. A more complete description of the hydrology of the area and the model is presented by Wiele and Smith (1996). This report was prepared by the USGS in cooperation with the Bureau of Reclamation. 


\section{MODEL OVERVIEW}

Wiele and Smith (1996) described a one-dimensional model of the propagation of diurnal-discharge waves down the Colorado River between Glen Canyon Dam and Lake Mead. In that paper, the equations of motion were scaled, and it was demonstrated that the wave evolution and progression could be represented by the diffusion equation, as derived by Lighthill and Whitham (1955):

where

$$
\frac{\partial h}{\partial t}+S_{*}^{0.5} \frac{d Q_{k}}{d A} \frac{\partial h}{\partial x}-\frac{Q_{k}}{2 b S S_{*}^{0.5}} \frac{\partial^{2} h}{\partial x^{2}}=0,
$$

$$
\begin{aligned}
h & =\text { water depth, } & A & =\text { cross-sectional area, } \\
t & =\text { time, } & x & =\text { streamwise coordinate, } \\
S_{*} & =1-(\partial h / \partial x) / S, & S & =\text { steady-flow water-surface slope, and } \\
Q_{k} & =\text { steady-flow discharge, } & b & =\text { channel-top width. }
\end{aligned}
$$

Equally as important as the governing-flow equation are the physical characteristics of the river channel. A characteristic channel shape was formed by averaging the 199 cross sections measured by Wilson (1986). The channel friction was determined at three values of the hydraulic radius corresponding to 142,425 , and $800 \mathrm{~m}^{3} / \mathrm{s}$ and a line was fit through them. The channel friction at $800 \mathrm{~m}^{3} / \mathrm{s}$ was calculated from the Wilson cross sections, and the intermediate channel friction was calculated from a dye study conducted at a steady $425 \mathrm{~m}^{3} / \mathrm{s}$ that provided reach-averaged flow velocities (Graf, 1995). The low-discharge channel friction was calculated from measured wave speeds, and the channel friction was calculated at $425 \mathrm{~m}^{3} / \mathrm{s}$. The details of these calculations can be found in Wiele and Smith (1996). The model proved to be accurate over the modeled reach of the river (fig. 1; about $380 \mathrm{~km}$ ) and over the extremely high discharge ranges up to an order of magnitude that have characterized typical dam operation (Wiele and Smith, 1996).

\section{DATA USED IN MODEL MODIFICATIONS}

\section{Characteristics of the Controlled Flood}

The controlled flood consisted of a steady low flow of $226 \mathrm{~m}^{3} / \mathrm{s}$ for 96 hours, an increase to $1,270 \mathrm{~m}^{3} / \mathrm{s}$ over a 10 -hour period where it was held steady for 167 hours, then a gradual decrease to $226 \mathrm{~m}^{3} / \mathrm{s}$ over a 46-hour period (fig. 2). The falling limb receded slowly to minimize erosion by sapping of anticipated new sand deposits (Tim Randle, Bureau of Reclamation, oral commun., 1996). This slow rate at which the flow was decreased allows for the simplification of equation 1 when applied to this part of the flow and the inference of the hydraulic geometry of up to $1,270 \mathrm{~m}^{3} / \mathrm{s}$.

\section{Streamflow-Gaging Station Data}

Four streamflow-gaging stations currently operate on the Colorado River between Glen Canyon Dam and Lake Mead (fig. 1).

1. Colorado River at Lees Ferry (09380000), river mile (RM) 0, $25 \mathrm{~km}$ below the dam. 


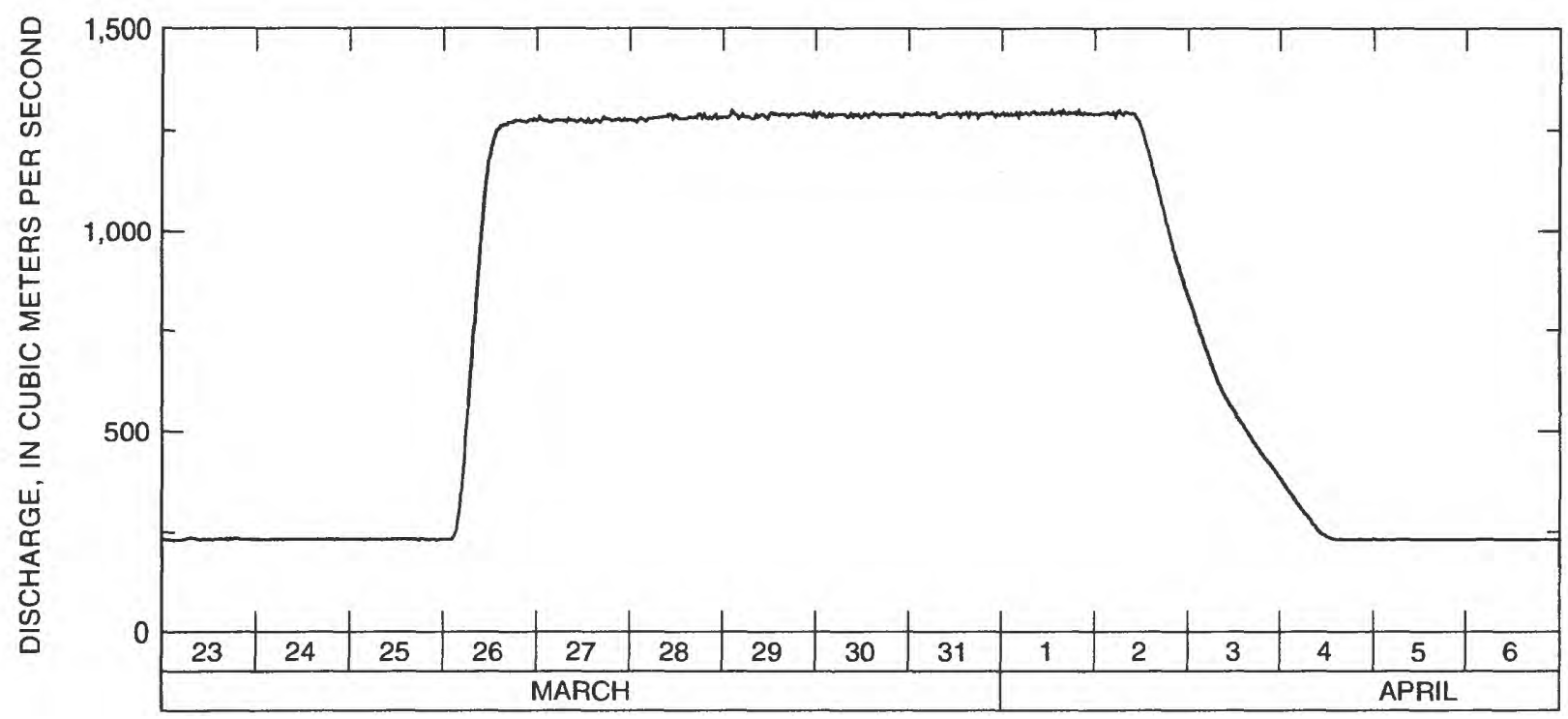

Figure 2. Hydrograph for the controlled flood released from Glen Canyon Dam, March-April 1996.

2. Colorado River above the Little Colorado River near Desert View (09383100), RM 61, 124 km below the dam.

3. Colorado River near Grand Canyon (09402500), RM 88, $165 \mathrm{~km}$ below the dam.

4. Colorado River above Diamond Creek near Peach Springs (09404200), RM 225, 386 km below the dam.

Streamflow-gaging station, Colorado River below Glen Canyon Dam (09379910) was not operating at the time of the controlled flood, and the hydrograph for streamflow-gaging station, Colorado River above National Canyon near Supai (09404120, RM 166) was not available at the time of this analysis. Hydrographs for the streamflow-gaging station, Colorado River above National Canyon near Supai, however, were available for the research flows released in 1991. One of the research flows was used in the formulation of the original model, and that research flow as well as two more flows were used to test the original and modified models. Discharge from Glen Canyon Dam typically is determined from the magnitude of the power generated by the turbines. This method cannot be used to determine discharge if the release exceeds powerplant capacity and, as a result, a complete hydrograph of the dam release during the controlled flood was not available when this analysis was done. The calculations described below omitted the 25-kilometer reach of river between the dam and Lees Ferry. Instead, data from the streamflow-gaging station at Lees Ferry were used as input to the model and to calculate wave speeds.

\section{MODEL MODIFICATIONS}

\section{Governing Equations}

The momentum equation is

$$
\frac{\partial u}{\partial t}+u \frac{\partial u}{\partial x}+g\left(\frac{\partial e}{\partial x}-S\right)+\frac{u_{*}^{2}}{R_{h}}=0
$$


where

$$
\begin{aligned}
u & =\text { average velocity } \\
g & =\text { acceleration due to gravity, } \\
\frac{\partial e}{\partial x} & =\text { additional water-surface slope with respect to the average slope due to the shape of } \\
u_{*} & =\text { shear velocity, and } \\
R_{h} & =\text { hydraulic radius. }
\end{aligned}
$$

Following the procedure of Wiele and Smith (1996), the momentum equation (eq. 1) can be rearranged into a nondimensional form,

$$
\frac{1}{g S} \frac{\partial u}{\partial t}+\frac{u}{g S} \frac{\partial u}{\partial x}+\frac{\frac{\partial e}{\partial x}}{S}-1+\frac{u_{*}{ }^{2}}{R_{h} g S}=0
$$

that can be scaled to identify the significant terms. In Wiele and Smith (1996), the unsteady term, $[1 /(g S)](\partial u / \hat{c} t)$, is small and can be neglected for discharge waves generated by dam releases. As in the earlier model, the convective acceleration term, $[u /(g S)](\partial u / \partial x)$, is absorbed into the friction coefficient because it cannot be resolved with the available channel topography and because the energy loss represented by this term is included in the empirically derived friction coefficient. Neglecting these two terms in the momentum equation and combining the momentum equation with the continuity equation,

$$
\frac{\partial A}{\partial t}+\frac{\partial Q}{\partial x}=0
$$

leads to equation 1 (Lighthill and Whitham, 1955).

On the receding limb of the controlled flood, the momentum equation can be further simplified by neglecting the additional slope due to the wave shape represented by $(\partial e / \partial x) / S$. This term can be approximated by $(\partial h / \partial t) /\left(c_{w} S\right)$, in which $c_{w}$ is the wave speed. The wave speed and $\partial h / \partial t$ can be calculated with the hydraulic geometry used in the model, which predicts a change in $h$ between the high and low flow of about $4 \mathrm{~m}$ over the 46-hour duration of the receding limb and a wave speed of about $3 \mathrm{~m} / \mathrm{s}$. Substituting these values into $(\partial h / \partial t) /\left(c_{w} S\right)$ leads to a $(\bar{c} e / \partial x) / \mathrm{S}$ that is less than a 1-percent correction; therefore, this term can be neglected as well. For the receding limb of the controlled flood, the momentum equation thus can be reduced to:

$$
u_{*}=\left(g R_{h} S\right)^{\frac{1}{2}} .
$$

The receding limb of the controlled flood can be represented by combining equation 5 with the continuity equation (eq. 4) to yield the kinematic-wave equation (Lighthill and Whitham, 1955):

$$
\frac{\partial h}{\partial t}+c_{w} \frac{\partial h}{\partial x}=0,
$$

where $c_{w}$ is the kinematic-wave speed, $d Q_{k} / d A$. In equation 6 , the speed and evolution of the wave are functions only of the channel hydraulic geometry, unlike in equation 1 where the wave speed and evolution also are functions of wave shape. The time it takes for a given discharge on the receding limb to travel from gaging station to gaging station, therefore, is simply a result of the average kinematic-wave speed $\left(d Q_{k} / d A\right)$ between gaging stations.

\section{Calculation of Hydraulic Geometry}

The hydraulic geometry can be calculated by integrating $d Q_{k} / d A$ over the falling limb of the wave, which is governed by equation 6 , using one of the known values of the area at a given discharge to supply 
the integration constant. The known values of area-discharge pairs can be obtained from data in the dye study at $425 \mathrm{~m}^{3} / \mathrm{s}$, the cross sections measured by Wilson (1986) at $800 \mathrm{~m}^{3} / \mathrm{s}$, or from a dye study during the controlled flood (Konieczki and others, 1997).

In practice, it generally is easier to integrate a function fitted to $d A / d Q_{k}$, which allows for a separation of variables. Plotting $d A / d Q_{k}$ as a function of $Q_{k}$ and fitting three lines to the plot using a least-squares method yields:

$$
\begin{gathered}
c=\left(a_{o}+a_{1} \ln \left(Q_{k}\right)\right)^{-1} \text { if } Q_{k}<=623.5 \mathrm{~m}^{3} / \mathrm{s}, \\
c=\left[b_{o}+b_{1} \ln \left(Q_{k}\right)+b_{2}\left(\ln \left(Q_{k}\right)\right)^{2}\right]^{-1} \text { if } 623.5 \mathrm{~m}^{3} / \mathrm{s}<Q_{k}<=715 \mathrm{~m}^{3} / \mathrm{s}, \\
c=\left(c_{o}+c_{1} \ln \left(Q_{k}\right)\right)^{-1} \text { if } 715 \mathrm{~m}^{3} / \mathrm{s}<Q_{k},
\end{gathered}
$$

where

$$
\begin{array}{lll}
a_{o}=1.491, & b_{1}=-2.599, & c_{o}=0.7774, \text { and } \\
a_{1}=-0.1781, & b_{2}=0.1909, & c_{1}=-0.06821 . \\
b_{o}=9.1638 & &
\end{array}
$$

Equation 7 and the wave speeds taken from the hydrographs at Lees Ferry and Diamond Creek are shown in figure 3. The wave speeds measured from the hydrographs recorded during the controlled flood at Lees Ferry and Diamond Creek are close to the wave speeds calculated using the previous version of the model for discharges up to about $700 \mathrm{~m}^{3} / \mathrm{s}$ (fig. 3). Above $700 \mathrm{~m}^{3} / \mathrm{s}$, the extrapolated wave speed from the previous model exceeds the wave speeds measured from the hydrographs.

Integrating equations $7 A, 7 B$, and $7 C$, using the cross-sectional area from the measurements by Wilson (1986) made at a known discharge to get an integration constant, and matching equations $7 A$ and $7 B$ at their limits to $7 C$ yields a new relation between $Q_{k}$ and $A$ :

$$
\begin{gathered}
A=188.46+a_{o} Q_{k}+a_{1} Q_{k}\left(\ln Q_{k}-1\right) \text { if } Q_{k}<=623.5 \mathrm{~m}^{3} / \mathrm{s}, \\
A=27.408+b_{o} Q_{k}+b_{1} Q_{k}\left(\ln Q_{k}-1\right)+b_{2} Q_{k}\left[\left(\ln \left(Q_{k}\right)\right)^{2}-2 \ln Q_{k}+2\right] \\
\text { if } 623.5 \mathrm{~m}^{3} / \mathrm{s}<Q_{k}<=715 \mathrm{~m}^{3} / \mathrm{s}, \\
A=261.11+c_{o} Q_{k}+c_{1} Q_{k}\left(\ln Q_{\mathrm{k}}-1\right) \text { if } 715 \mathrm{~m}^{3} / \mathrm{s}<Q_{k} .
\end{gathered}
$$

The friction coefficient, $\beta$, can be determined by rearranging

$$
Q_{k}=\beta A u_{*}
$$

using the characteristic cross section to provide a relation between $A$ and $R_{h}$ (Wiele and Smith, 1996), solving for a number of values of $\beta$ and $R_{h}$, and fitting a line to the result using a least-squares method. This procedure leads to the relation (fig. 4):

$$
\beta=-5.252+4.932 \ln R_{h} .
$$

Equations 7, 8, and 10 are in SI units.

In the previous model, the kinematic-wave speed, $d Q_{k} / d A$, was calculated by differentiating the relation between $Q_{k}$ and $A$ taken from the friction coefficient as a function of hydraulic radius and a relation between hydraulic radius and cross-sectional area taken from the characteristic cross section. Following a similar procedure using equations 9 and 10 and the same relation between $R_{h}$ and $A$ used in the previous model, however, results in a calculated wave speed that misses the inflection at about 


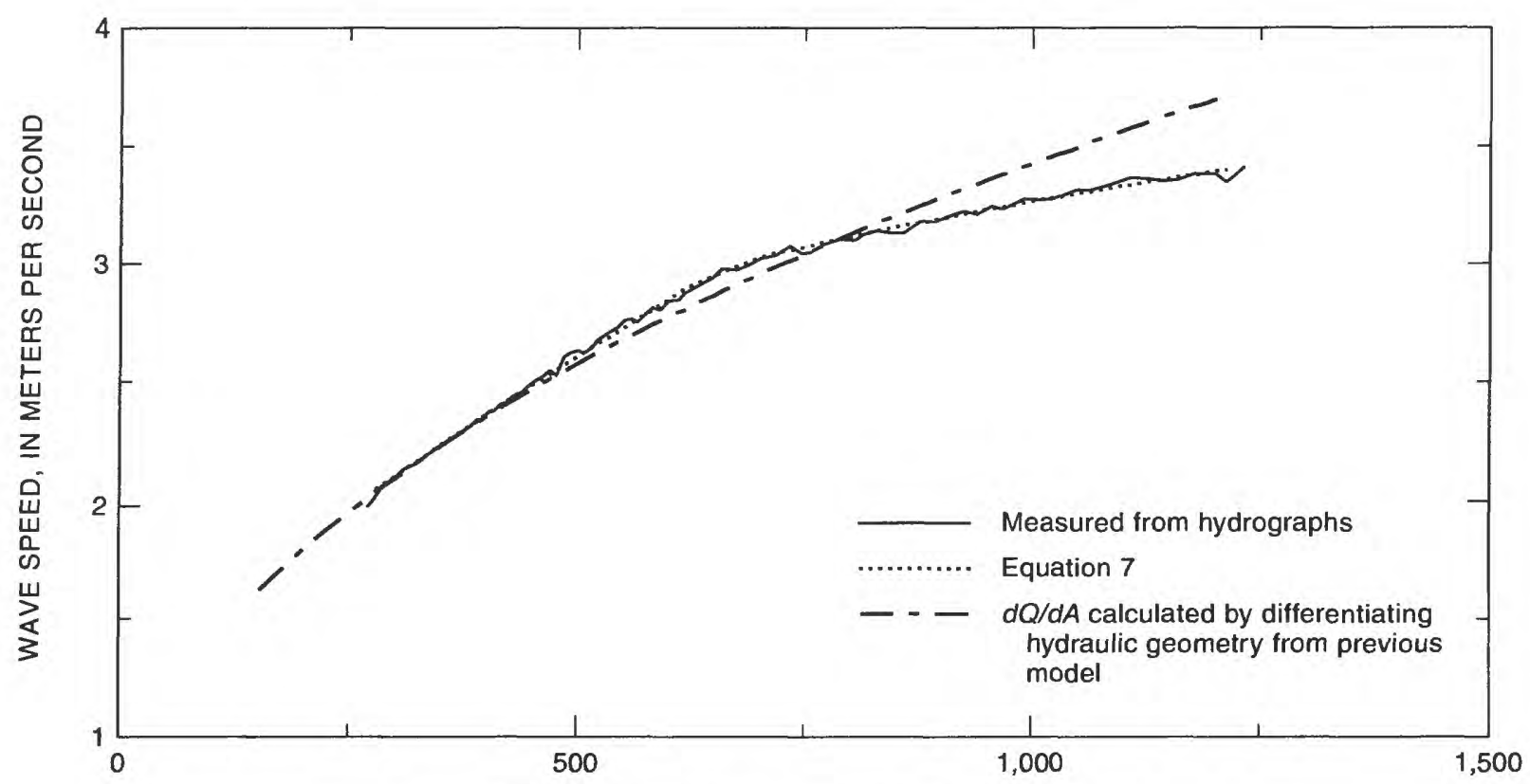

DISCHARGE, IN CUBIC METERS PER SECOND

Figure 3. Wave speed calculated from the hydrographs from the streamflow-gaging stations, Colorado River at Lees Ferry and Colorado River above Diamond Creek near Peach Springs, calculated with equation 7 , and calculated by differentiating the steady-flow discharge as a function of area calculated from the hydraulic geometry used in the original model.

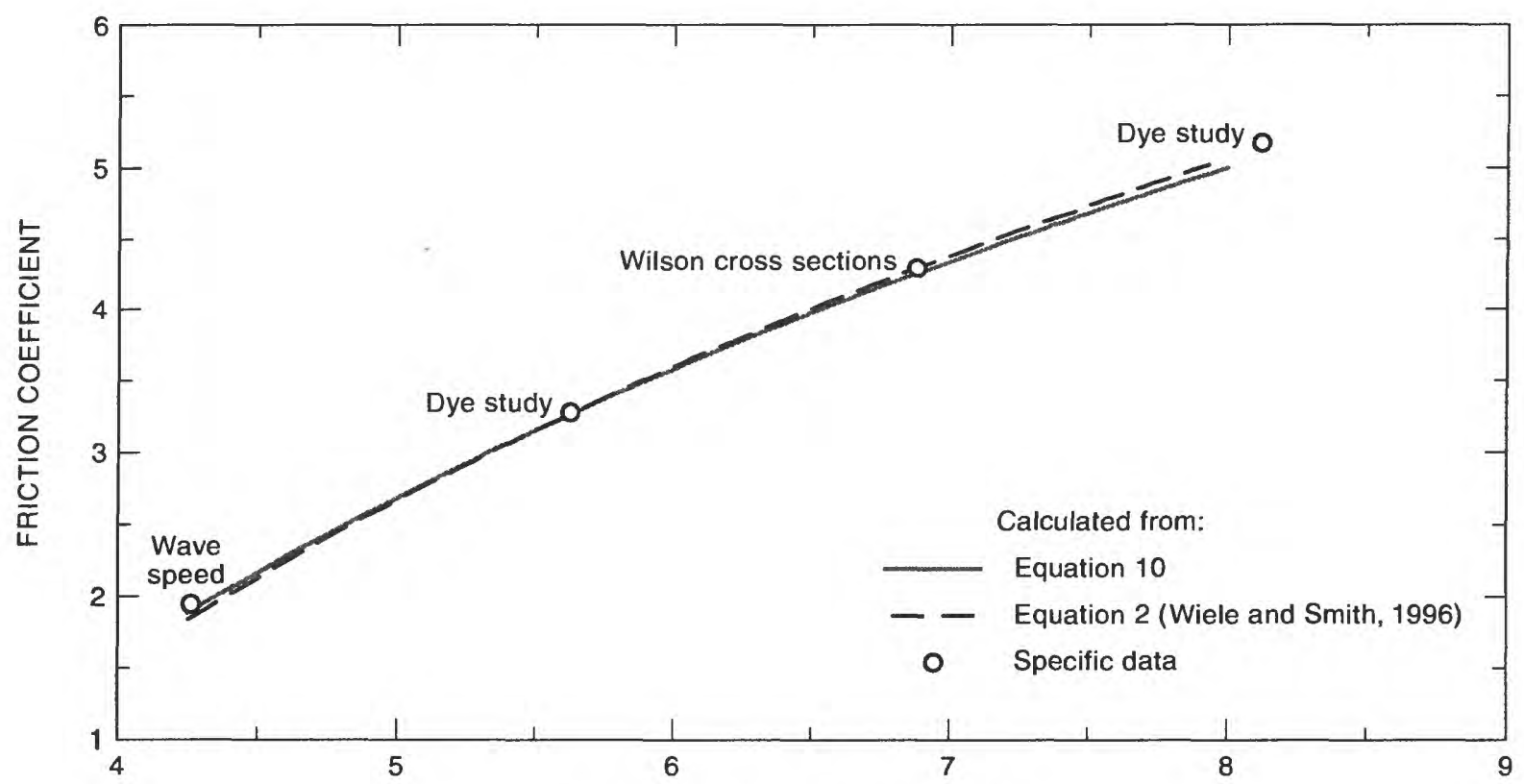

HYDRAULIC RADIUS, IN METERS

Figure 4. Relation between friction coefficient, $\beta$, and the hydraulic radius. Cross sections are from Wilson (1986). 
$700 \mathrm{~m}^{3} / \mathrm{s}$ (fig. 5), although equation 10 represents well the friction factor as a function of hydraulic radius and has an $r^{2}$ value greater than 0.99 . This failure to capture the inflection at $700 \mathrm{~m}^{3} / \mathrm{s}$ by differentiating the modified hydraulic geometry results from very small deviations of the line fit to $\beta$ from the points calculated with equation 9 . This can be demonstrated by first plotting $\beta=Q_{k} /\left(A u_{*}\right)$ against $R_{h}$ in which $A$ is taken from equation 8 , and then plotting $\beta$ against $R_{h}$ in which $\beta$ is taken from equation 10 . The result shows that equation 10 represents $\beta$ well (fig. 6). Taking the numerical derivatives of both lines, however, shows that the derivative of $\beta$ taken from the lines fit directly to data, $\beta=Q_{k} /\left(A u_{*}\right)$, and shows the inflection at $700 \mathrm{~m}^{3} / \mathrm{s}$; whereas, $\beta$ taken from equation 10 does not show the inflection (fig. 7 ). Equation 10 smooths out this inflection although this is not readily apparent in figure 6.

In most rivers in which steady discharge is a smooth function of area, fitting a smooth curve to a few known points can represent the hydraulic geometry well. In this case, however, such a maneuver would fail to capture the inflection that is crucial to accurately modeling wave speed at higher discharges. The new relation between $\beta$ and $R_{h}$ appears nearly identical to the original one, even where the original one is extrapolated above $700 \mathrm{~m}^{3} / \mathrm{s}$, but the wave speed as a function of discharge in the modified model is now determined from equation 7 rather than from the derivative of the discharge with respect to area calculated directly from the hydraulic geometry.

Inferring wave speed from data from streamflow-gaging stations depends on the accuracy of the stage-discharge relation for each gaging station. The reliability of the rating curves in this discharge range, however, is degraded because the range is above powerplant capacity; therefore, opportunities to measure the river at these discharges generally are rare.

The method used to calculate the hydraulic geometry described in this report requires a slow rate of discharge decrease. But with the very slow rate of decrease on the receding limb of the controlled flood, even small errors in the stage-discharge relations can lead to inconsistencies between hydrographs at the streamflow-gaging stations (fig. 8) and to irregular or even impossible relations between wave speed and discharge, especially if the gaging stations are close together (fig. 9). The gaging stations, Colorado River near Grand Canyon (09402500) and Colorado River above the Little Colorado River near Desert View

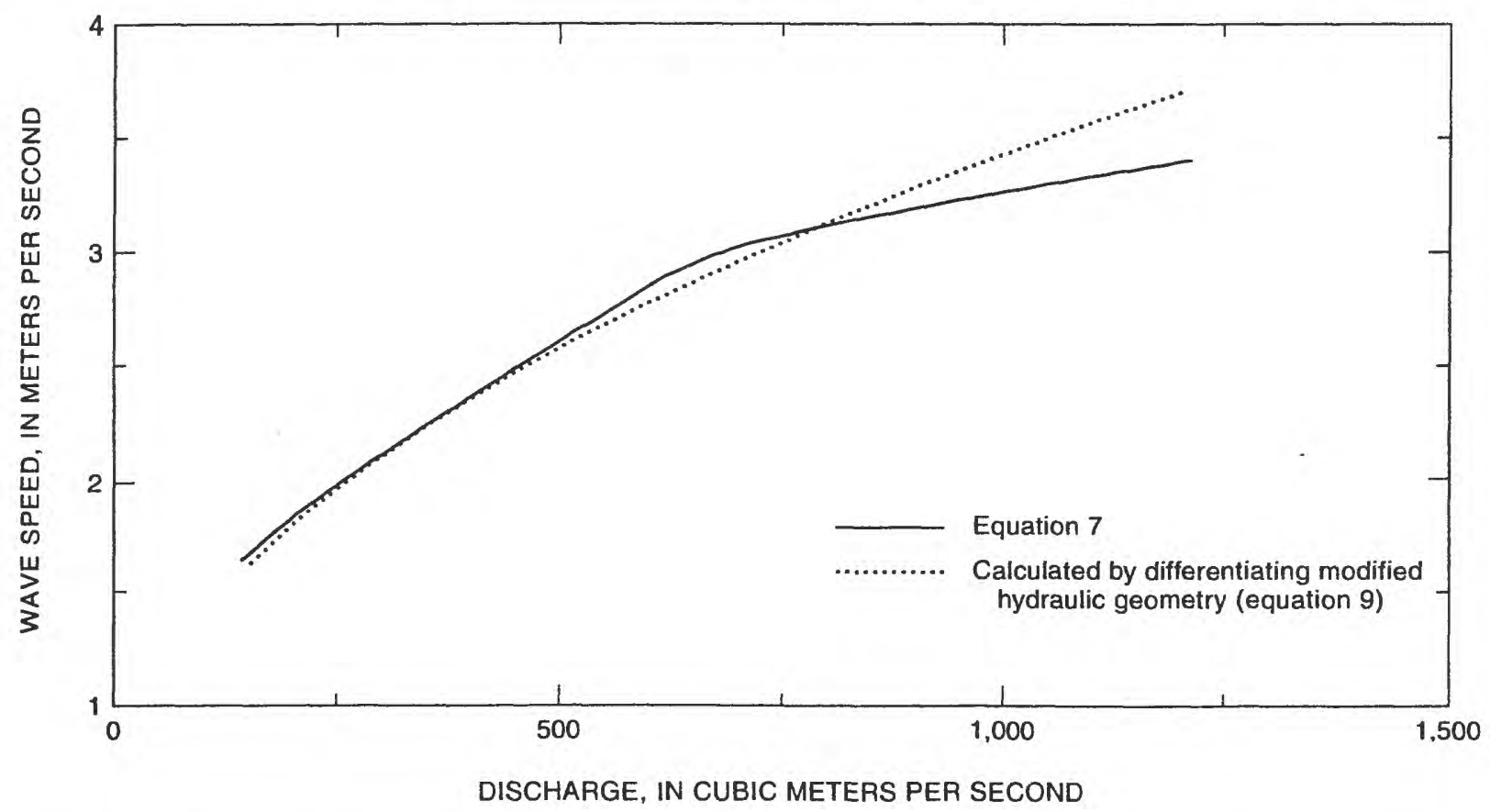

Figure 5. Wave speeds calculated with equation 7 and by differentiating discharge $(Q)$ with respect to crosssectional area $(A)$ in equation 9. 


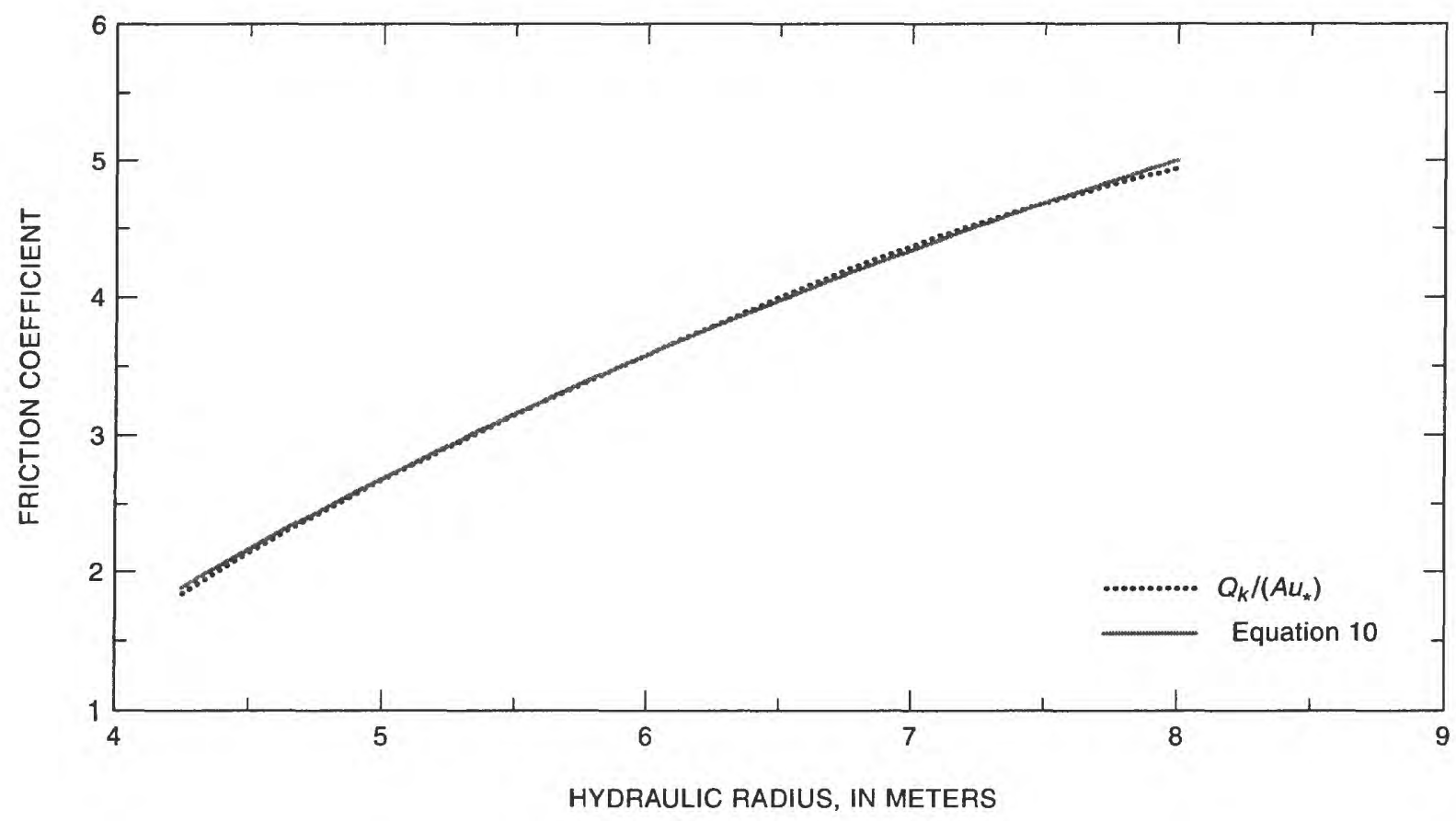

Figure 6. Relation between the hydraulic radius and the friction coefficient, $\beta$, calculated using equation 9 $\left(\beta=Q_{k} /\left(A u_{\star}\right)\right)$ in which cross-sectional area $(A)$ is taken from equation 8 and using equation 10.

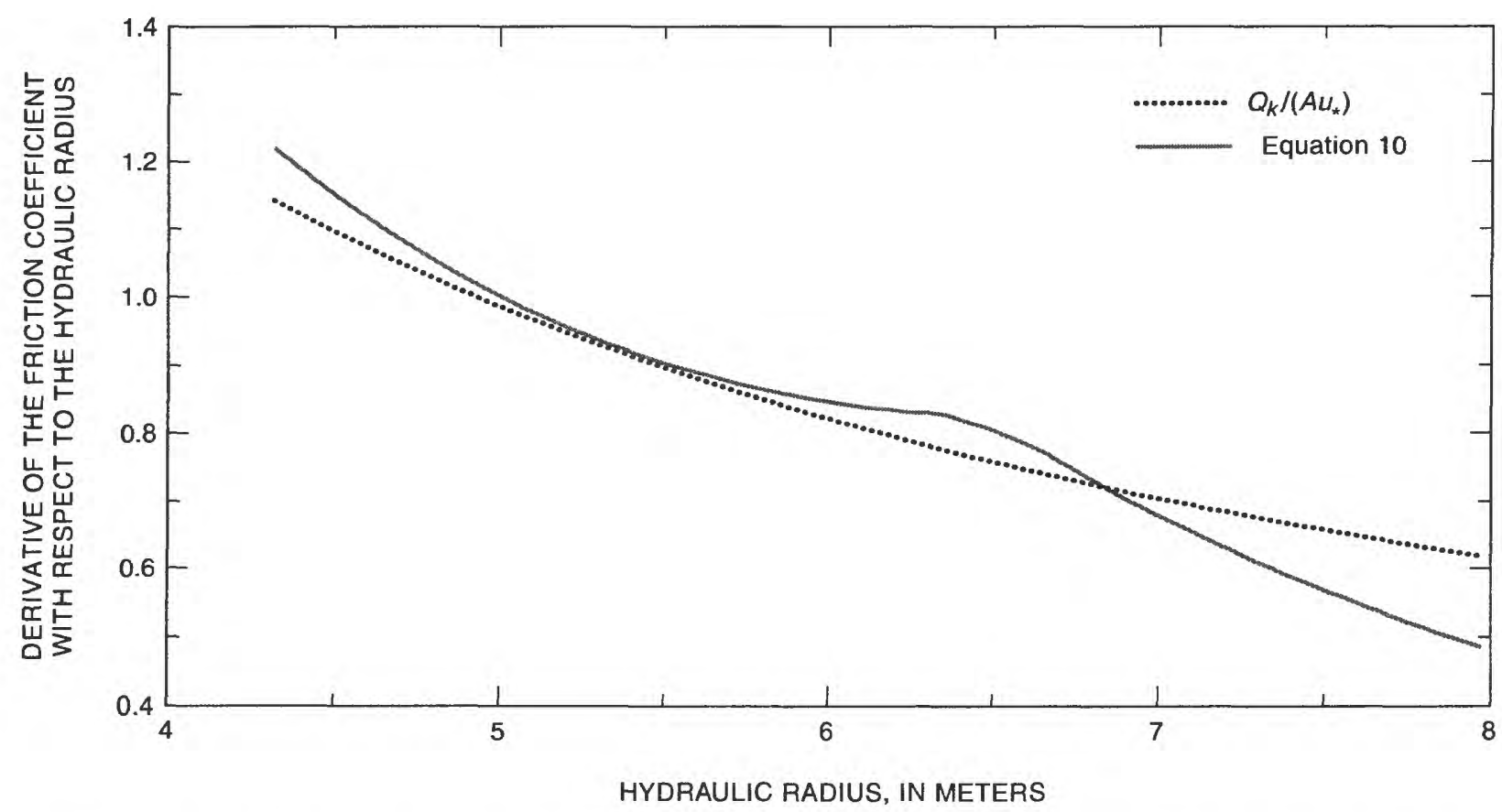

Figure 7. The derivative of the friction coefficient, $\beta$, with respect to the hydraulic radius plotted against the hydraulic radius. 
(09383100), are only $43 \mathrm{~km}$ apart. On the receding limb of the controlled flood, the discharge was lowered at a rate of $28.3\left(\mathrm{~m}^{3} / \mathrm{s}\right) / \mathrm{hr}$ when the discharge was between 976 and $580 \mathrm{~m}^{3} / \mathrm{s}$. At $976 \mathrm{~m}^{3} / \mathrm{s}$, the wave speed is $3.25 \mathrm{~m} / \mathrm{s}$. As a result of this slow decline in discharge and the short distance between gaging stations, a combined error of $105 \mathrm{~m} / \mathrm{s}$ in the two rating curves at a discharge of $976 \mathrm{~m}^{3} / \mathrm{s}$ would place that discharge at the two gaging stations at the same time.

With sufficient data, the accuracy of this flow model could be increased if more than one hydraulic geometry were used to represent the different sections of the channel. Because of the sensitivity of the method used to modify the model to the rating curves and the slow decrease of the receding limb of the controlled-flood hydrograph, dividing the channel into multiple reaches was found to be impractical, and a single hydraulic geometry for the entire reach was retained. Using the gaging-station record at Lees Ferry and above Diamond Creek near Peach Springs, which are $386 \mathrm{~km}$ apart, yields a smooth consistent relation between wave speed and discharge (fig. 3 ).

One possible source for error with this method that has not been accounted for is the effect of bank storage. As the stage drops, water stored in the channel banks during the week-long high flow will be released to the main channel increasing the discharge above that expected if only wave propagation was considered.

\section{Numerical Method}

In addition to modifying the hydraulic geometry by extending it to a higher discharge, the numerical method used in the solution of equation 1 has been changed. In Wiele and Smith (1996), a fully implicit numerical method was used. The curvature of the hydrographs in the controlled flood, however, is sharper than in previously available flows. This increase in curvature results in greater sensitivity to the numerical method because the sharper curvature tends to enhance numerical diffusion. The numerical diffusion inherent in a fully implicit method did not significantly affect the results in the cases tested by Wiele and Smith (1996). The modified model uses a Crank-Nicholson method (Anderson and others, 1984). The Crank-Nicholson method time centers the solution by averaging an explicit solution and an implicit solution at each time step. This procedure reduces excessive numerical diffusion, allowing for more accurate representation of wave propagation under more extreme conditions such as the controlled flood.

\section{COMPARISON OF MODEL RESULTS WITH DATA}

The modified hydraulic geometry is close to the hydraulic geometry used in the original model. As a result, the differences in model predictions are small for flows with peak discharges that are less than powerplant capacity. In Wiele and Smith (1996), the accuracy of the model was evaluated by comparing model predictions to hydrographs recorded during several research flows that consisted of daily flows that fluctuated between specified ranges and that were preceded and followed by a steady flow of $142 \mathrm{~m}^{3} / \mathrm{s}$. Research flows B and D ranged between 142 and $425 \mathrm{~m}^{3} / \mathrm{s}$ and between 85 and $793 \mathrm{~m}^{3} / \mathrm{s}$, respectively. The modified model results are similar to the original model results for flow B (fig. 10) and D (fig. 11).

The falling limb of the hydrograph from the controlled flood is governed by the kinematic-wave equation, and the rising limb is governed by the diffusion-wave equation (eq. 1). Thus the rising limb of the hydrograph serves as a test of the modified model independent of the falling limb even though the falling limb was used to derive the new hydraulic geometry. The modified model shows improved accuracy for high flows at all gaging stations (figs. 12, 13, and 14). The average absolute errors in time for the modified and original model are shown for the rising limb (table 1) and for the falling limb (table 2). In addition to listing the average absolute errors, tables 1 and 2 show the average absolute errors 


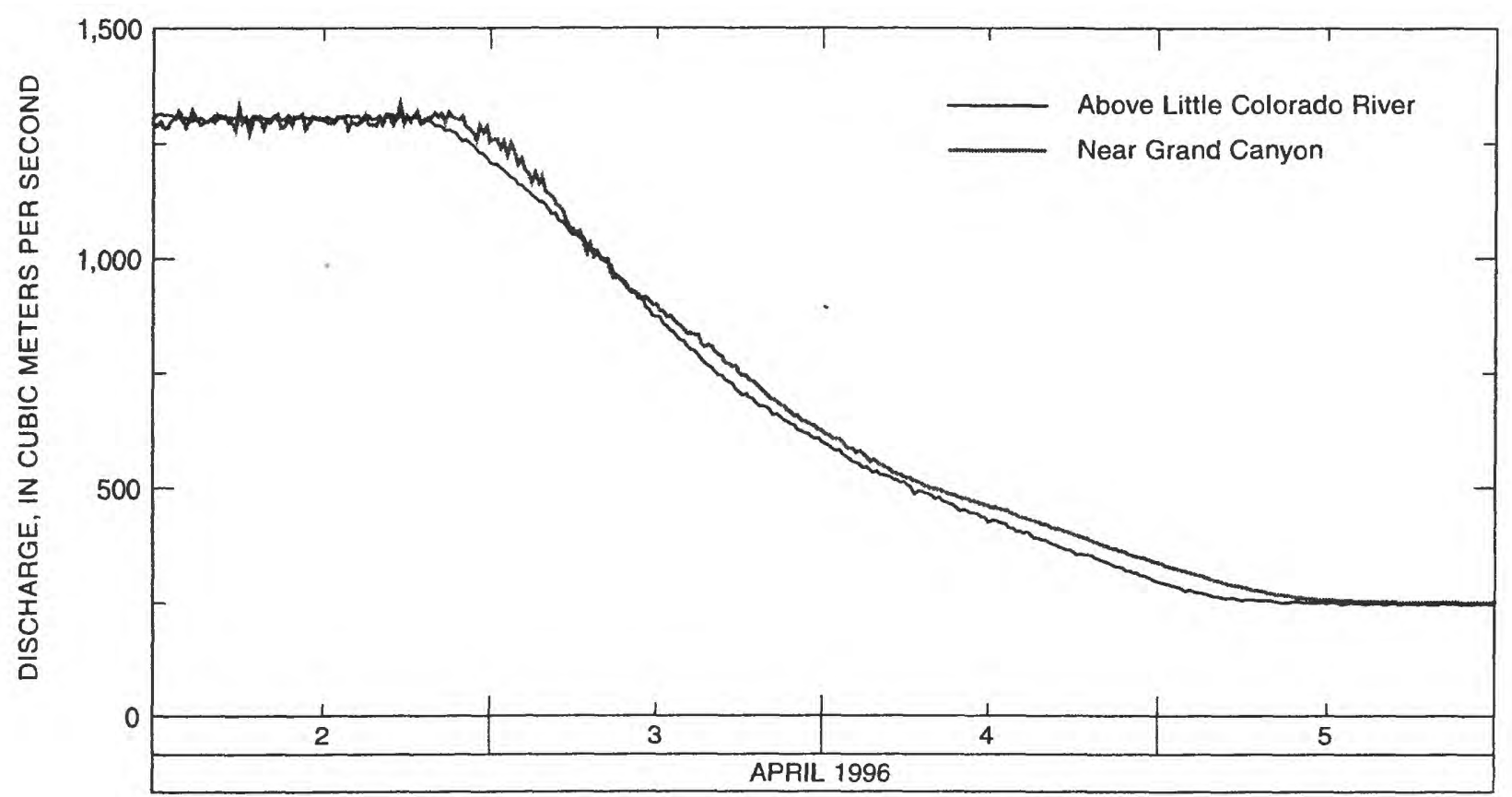

Figure 8. Hydrographs determined from stage records and stage-discharge relations at streamflow-gaging stations, Colorado River above the Little Colorado River near Desert View and Colorado River near Grand Canyon, for the receding limb of the controlled flood.

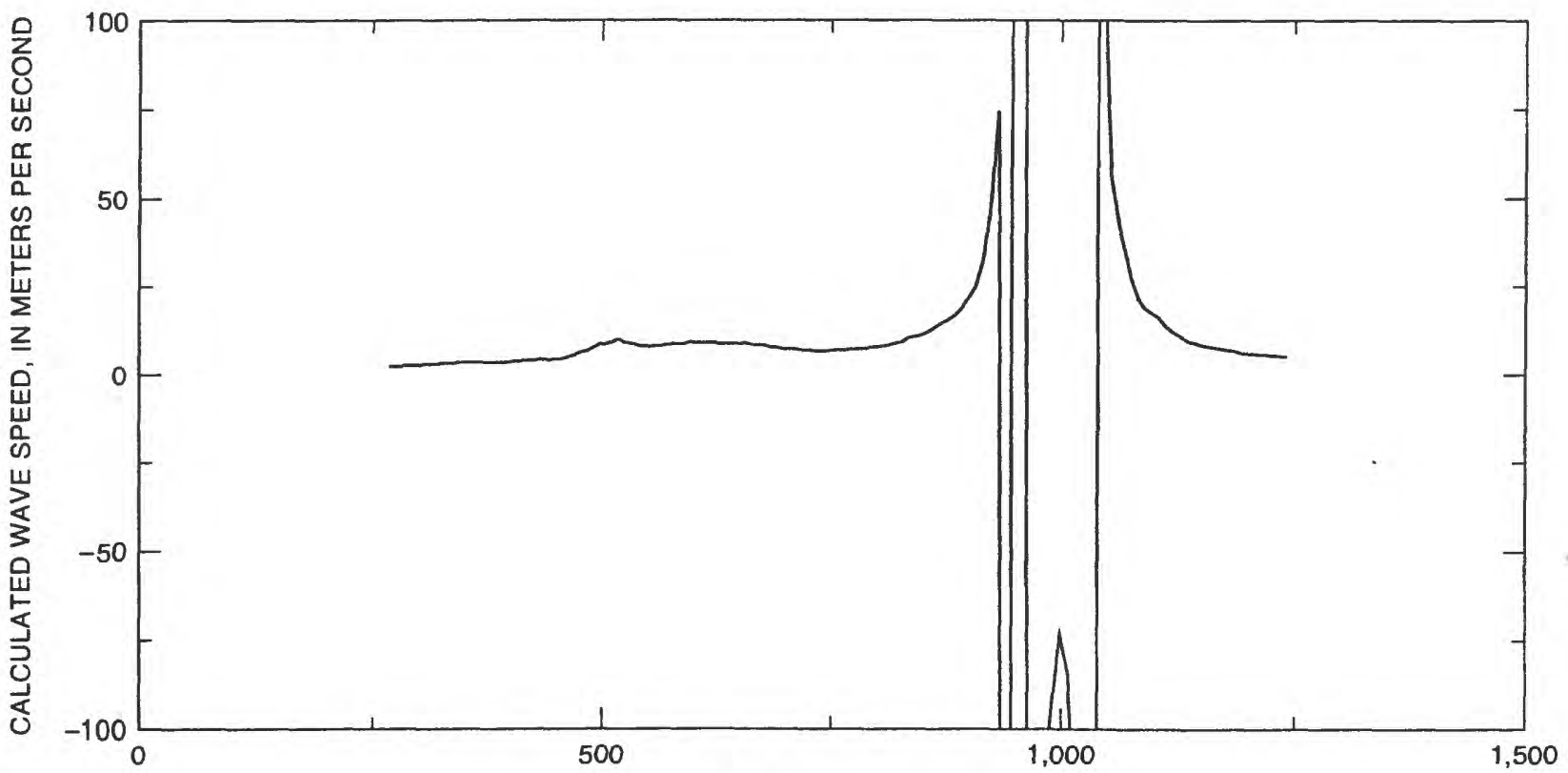

DISCHARGE, IN CUBIC METERS PER SECOND

Figure 9. Wave speeds calculated from the hydrographs shown in figure 8 . The long time of the falling limb makes calculation of wave speeds sensitive to the stage-discharge relations if the gaging stations are too close together. 
Table 1. Model error on rising limb of controlled flood at three streamflow-gaging stations for the original and modified models

\begin{tabular}{|c|c|c|c|c|}
\hline \multirow[b]{2}{*}{ Gaging station and number } & \multicolumn{2}{|c|}{ Original model } & \multicolumn{2}{|c|}{ Modified model } \\
\hline & $\begin{array}{l}\text { Average absolute } \\
\text { error, in hours }\end{array}$ & $\begin{array}{c}\text { Average absolute } \\
\text { error normalized } \\
\text { by wave travel } \\
\text { time }\end{array}$ & $\begin{array}{l}\text { Average absolute } \\
\text { error, in hours }\end{array}$ & $\begin{array}{c}\text { Average absolute } \\
\text { error normalized } \\
\text { by wave travel } \\
\text { time }\end{array}$ \\
\hline \multicolumn{5}{|l|}{ Colorado River above Little } \\
\hline Colorado River $(09383100 \ldots \ldots \ldots \ldots$ & 1.7 & 0.16 & 1.0 & 0.10 \\
\hline \multicolumn{5}{|l|}{ Colorado River near Grand } \\
\hline 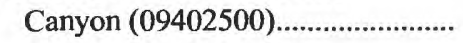 & 1.1 & .080 & .57 & .040 \\
\hline \multicolumn{5}{|l|}{ Colorado River above Diamond } \\
\hline $\begin{array}{l}\text { Creek near Peach Springs } \\
(09404200)\end{array}$ & 1.6 & .045 & .32 & .0092 \\
\hline
\end{tabular}

Table 2. Model error on falling limb of controlled flood at three streamflow-gaging stations for the original and modified models

\begin{tabular}{|c|c|c|c|c|}
\hline \multirow[b]{2}{*}{ Gaging station and number } & \multicolumn{2}{|c|}{ Original model } & \multicolumn{2}{|c|}{ Modified model } \\
\hline & $\begin{array}{l}\text { Average absolute } \\
\text { error, in hours }\end{array}$ & $\begin{array}{l}\text { Average absolute } \\
\text { error normalized } \\
\text { by time of fall }\end{array}$ & $\begin{array}{l}\text { Average absolute } \\
\text { error, in hours }\end{array}$ & $\begin{array}{l}\text { Average absolute } \\
\text { error normalized } \\
\text { by time of fall }\end{array}$ \\
\hline \multicolumn{5}{|l|}{ Colorado River above Little } \\
\hline Colorado River (09383100 & 3.6 & 0.069 & 3.2 & 0.062 \\
\hline \multicolumn{5}{|l|}{ Colorado River near Grand } \\
\hline Canyon (09402500) & 1.4 & .026 & 1.1 & 0.019 \\
\hline \multicolumn{5}{|l|}{ Colorado River above Diamond } \\
\hline $\begin{array}{l}\text { Creek near Peach Springs } \\
(09404200)\end{array}$ & .76 & .011 & .39 & .0057 \\
\hline
\end{tabular}

normalized by an appropriate time scale. For the rising limb, the travel time of the midpoint of the wave was used. For the falling limb, the time of fall, taken to be the time over which the discharge decreased from 1,245 to $270 \mathrm{~m}^{3} / \mathrm{s}$, was used. This time scale was chosen to account for apparent error created by the long time of the fall and the sensitivity to the rating curves.

\section{SUMMARY}

The one-dimensional model of unsteady flow in the Colorado River between Glen Canyon Dam and Lake Mead presented by Wiele and Smith (1996) has been modified using data from the controlled flood of March-April 1996. Hydraulic geometry and wave speed were extended from about 800 to $1,270 \mathrm{~m}^{3} / \mathrm{s}$. In addition, a new numerical method is used that reduces numerical diffusion that would otherwise degrade the accuracy of the model's predictions of hydrographs with higher rates of change in discharge. The original version of the model was based on data collected at discharges up to $792 \mathrm{~m}^{3} / \mathrm{s}$ and required 


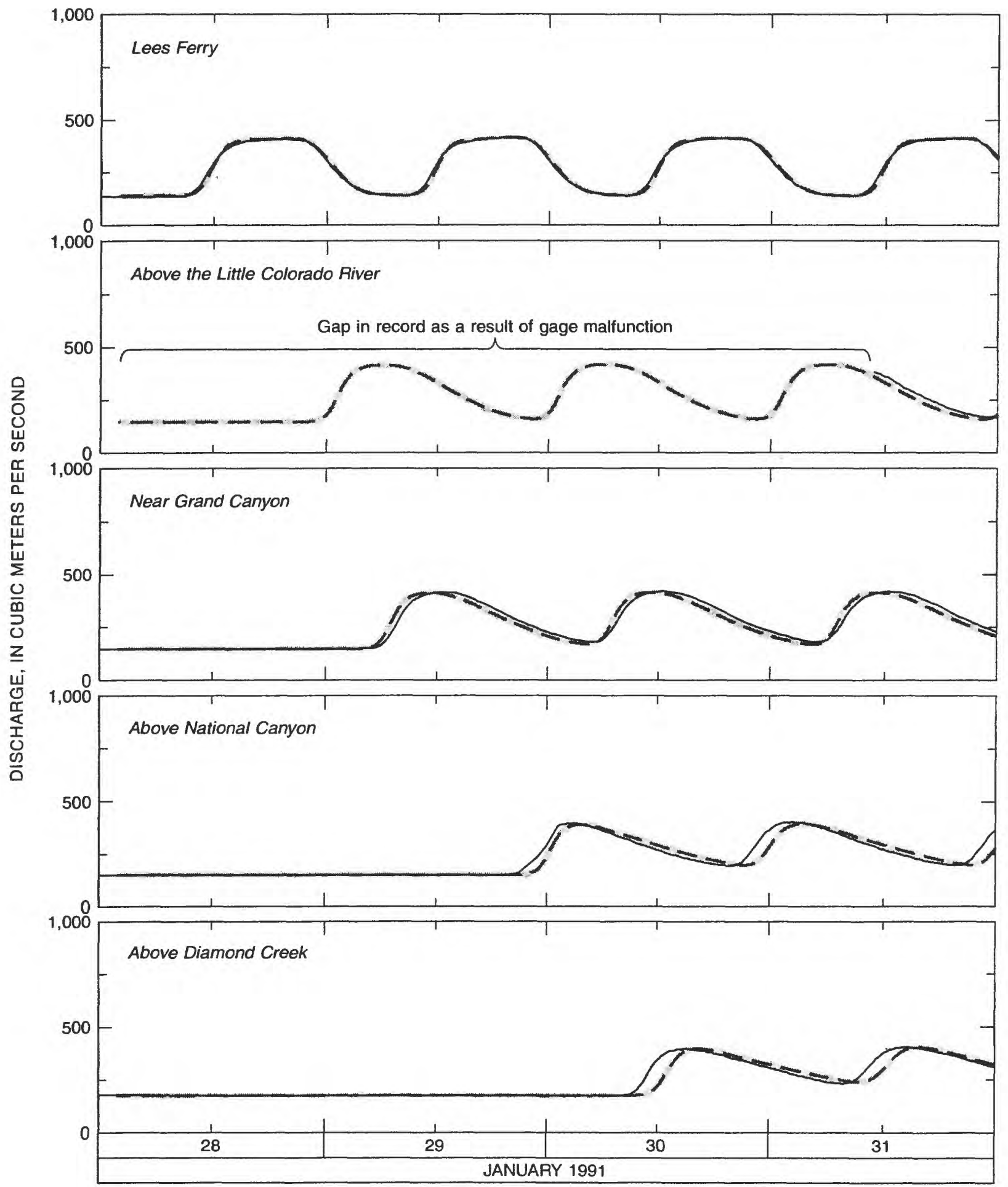

Figure 10. Hydrographs calculated with original (dashed lines) and modified (grey lines) models and hydrographs determined from stage records and the stage-discharge relations (solid lines) for research flow $B$ at streamflow-gaging stations, Colorado River at Lees Ferry, Colorado River above the Little Colorado River near Desert View (RM 61), Colorado River near Grand Canyon (RM 88), Colorado River above National Canyon near Supai (RM 166), and Colorado River above Diamond Creek near Peach Springs (RM 225). The hydrographs are positioned to show the rise of the first wave following the steady flow with the exception of Colorado River, above the Little Colorado River near Desert View where the streamflow record is incomplete. 


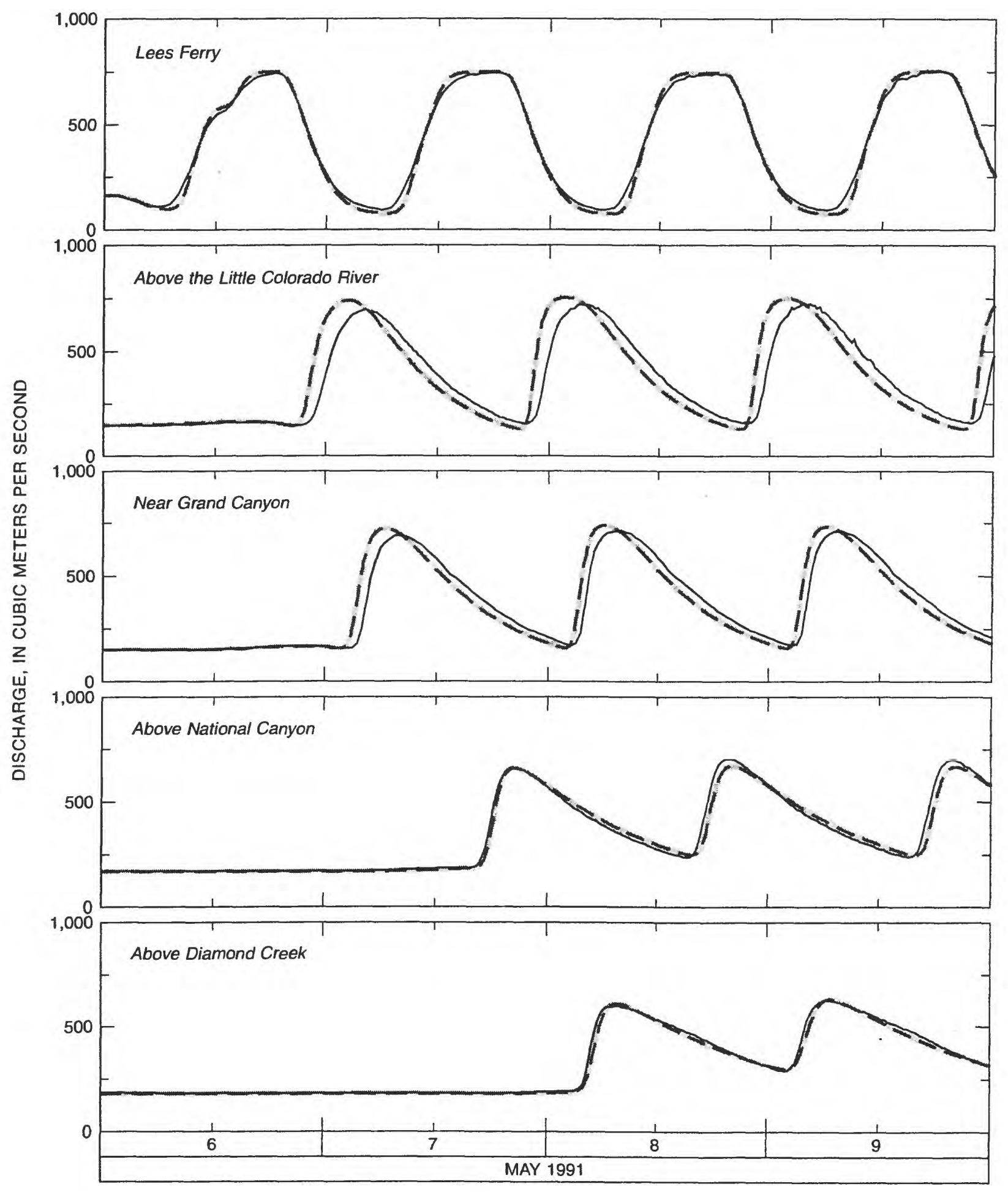

Figure 11. Hydrographs calculated with original (dashed lines) and modified (grey lines) models and hydrographs determined from stage records and the stage-discharge relations (solid lines) for research flow D at streamflow-gaging stations, Colorado River at Lees Ferry, Colorado River above the Little Colorado River near Desert View (RM 61), Colorado River near Grand Canyon (RM 88), Colorado River above National Canyon near Supai (RM 166), and Colorado River above Diamond Creek near Peach Springs (RM 225). The hydrographs are positioned to show the rise of the first wave following the steady flow.

14 Modifications to a One-Dimensional Model of Unsteady Flow in the Colorado River through the Grand Canyon, Arizona 

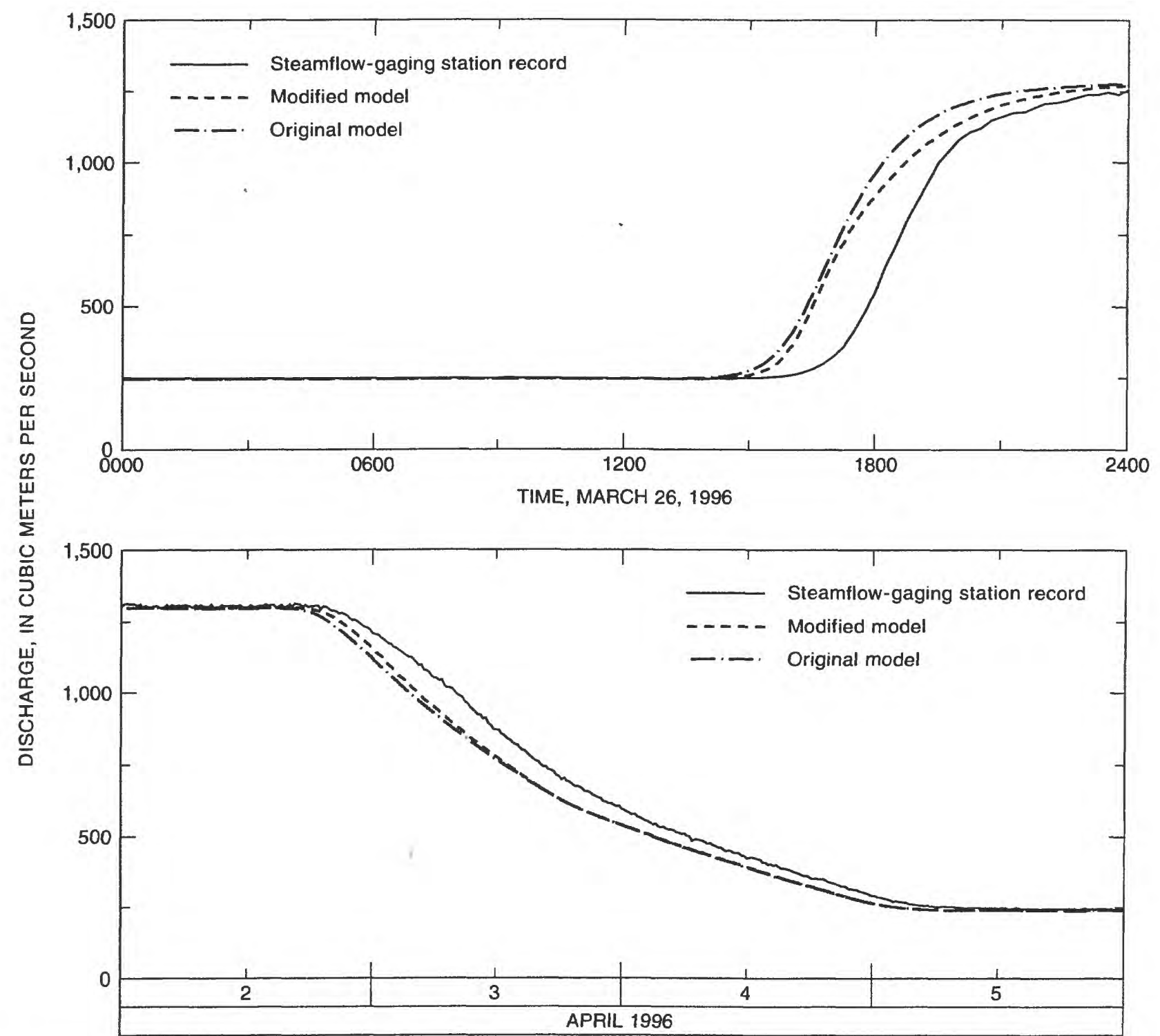

Figure 12. Hydrographs calculated with original and modified models and hydrographs determined from stage records and the stage-discharge relations for the rising (top) and falling (bottom) limbs of the controlled flood at streamflow-gaging station, Colorado River above Little Colorado River near Desert View.

extrapolation of the hydraulic geometry for higher discharges. The accuracy of the modified version is similar to the original version for discharges up to $792 \mathrm{~m}^{3} / \mathrm{s}$ but is more accurate at higher discharges.

\section{REFERENCES CITED}

Anderson, D.A., Tannehill, J.C., and Pletcher, R.H., 1984, Computational fluid mechanics and heat transfer: Washington, D.C., Hemisphere, 599 p.

Graf, J.B., 1995, Measured and predicted velocity and longitudinal dispersion at steady and unsteady flow, Colorado River, Glen Canyon Dam to Lake Mead: American Water Resources Association, Water Resources Bulletin, v. 31, no. 2, p. 265-281. 

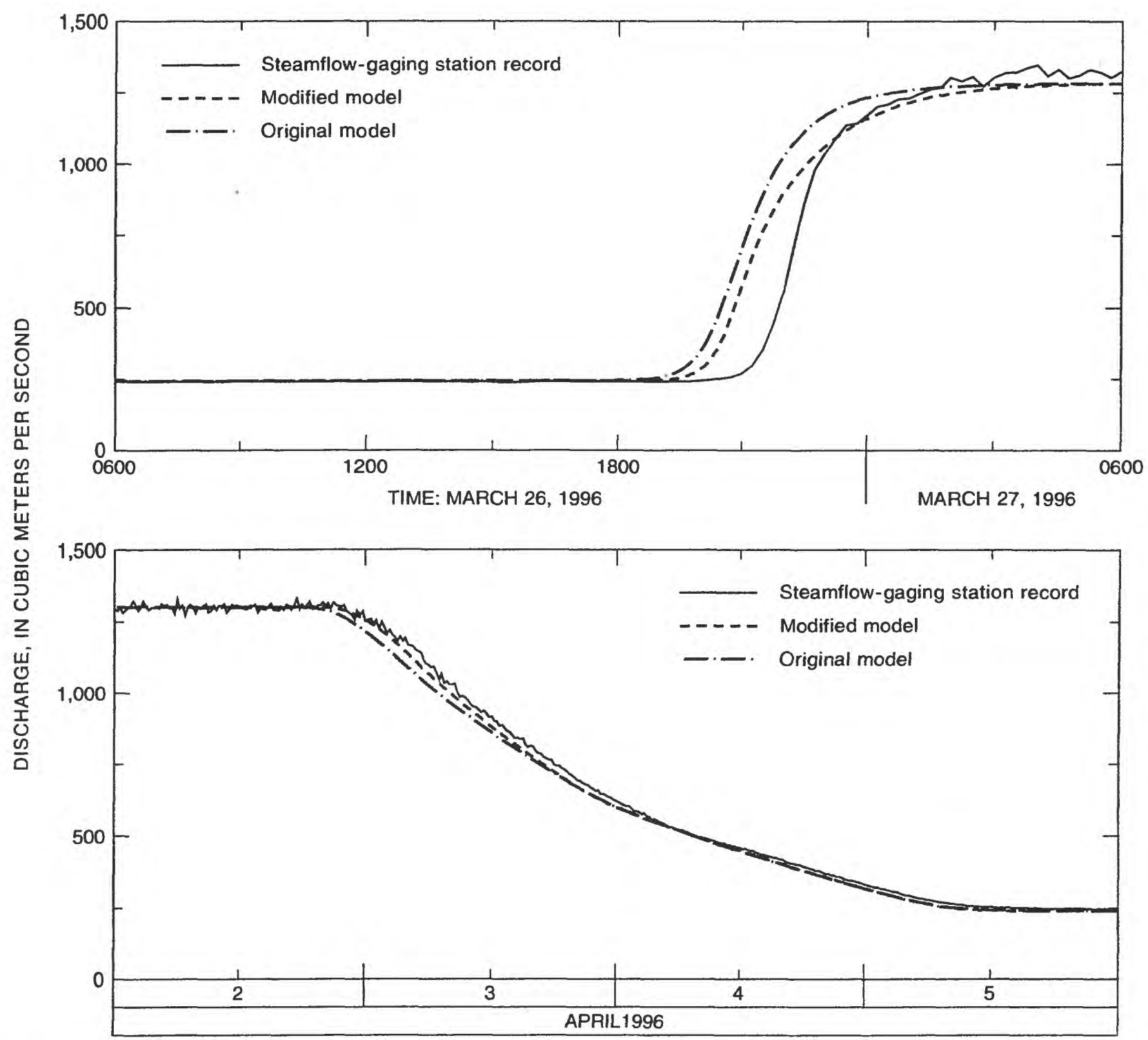

Figure 13. Hydrographs calculated with original and modified models and hydrographs determined from stage records and the stage-discharge relations for the rising (top) and falling (bottom) limbs of the controlled flood at streamflow-gaging station, Colorado River near Grand Canyon.

Griffin, E.R., and Wiele, S.M., 1995, Calculated hydrographs at selected sites along the Colorado River downstream from Glen Canyon Dam: U.S. Geological Survey Water-Resources Investigations Report 95-4266, 30 p.

Konieczki, A.D., Graf, J.B., and Carpenter, M.C., 1997, Streamflow and sediment data collected to determine the effects of a controlled flood in March and April 1996 on the Colorado River between Lees Ferry and Diamond Creek, Arizona: U.S. Geological Survey Open-File Report 97-224, 55 p.

Lighthill, M.J., and Whitham, G.B., 1955, On kinematic waves-I, Flood movement in long rivers: Proceedings of the Royal Society of London, Series A, v. 229, no. 1178, p. 281-316.

Wiele, S.M., 1996, Calculated hydrographs for the Colorado River downstream from Glen Canyon Dam during the experimental release, March 22-April 8, 1996: U.S. Geological Survey Fact Sheet FS-083-96, 1 sheet.

16 Modifications to a One-Dimensional Model of Unsteady Fiow in the Colorado River through the Grand Canyon, Arizona 

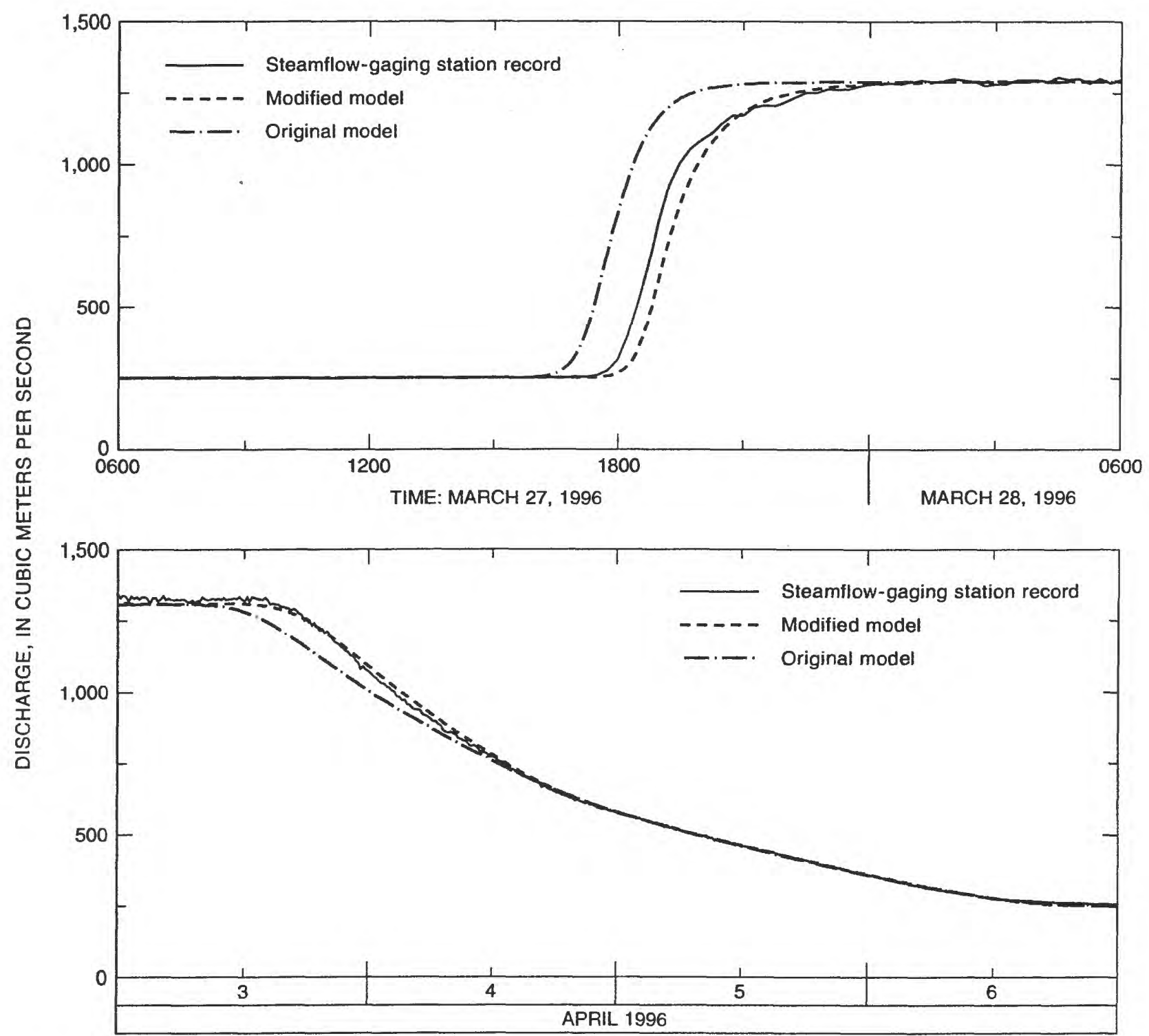

Figure 14. Hydrographs calculated with original and modified models and hydrographs determined from stage records and the stage-discharge relations for the rising (top) and falling (bottom) limbs of the controlled flood at streamflow-gaging station, Colorado River above Diamond Creek near Peach Springs.

Wiele, S.M., and Smith, J.D., 1996, A reach-averaged model of diurnal discharge wave propagation down the Colorado River through the Grand Canyon: American Geophysical Union, Water Resources Research, v. 32, no. 5 , p. $1375-1386$.

Wilson, R.P., 1986, Sonar patterns of the Colorado River bed, Grand Canyon: Fourth Federal Interagency Sedimentation Conference, v. 2, Las Vegas, Nevada, March 24-27, 1986, Proceedings, p. 5-133 to 5-142. 